ACTA UNIVERSITATIS WRATISLAVIENSIS

PRZEGLĄD PRAWA I ADMINISTRACJI CXX/1

WROCŁAW 2020

https://doi.org/10.19195/0137-1134.120.20

\author{
WOJCIECH KILARSKI \\ ORCID: 0000-0002-6621-3768 \\ Uniwersytet Wrocławski \\ Katedra Prawa Międzynarodowego i Europejskiego
}

\title{
KORPORACJE MIĘDZYNARODOWE JAKO PODMIOT (?) MIĘDZYNARODOWEGO PRAWA PRAW CZŁOWIEKA
}

\begin{abstract}
Abstrakt: Korporacja międzynarodowa jest uczestnikiem obrotu międzynarodowego, którego początków można szukać już w XVII wieku. Obecnie następstwa ich aktywności możemy zauważyć w różnych dziedzinach objętych prawem międzynarodowym, między innymi w międzynarodowym prawie praw człowieka. $Z$ jednej strony liczne są, dość dobrze udokumentowane, przykłady naruszeń praw człowieka, z drugiej — coraz częściej wyrażany jest pogląd o konieczności rozciągnięcia ochrony, dotychczas przysługującej człowiekowi, także na korporacje międzynarodowe. Dlatego istotne wydaje się określenie ich pozycji w międzynarodowym prawie praw człowieka.

Doktryna prawa międzynarodowego dysponuje licznymi próbami definicyjnymi, jednak żadna $\mathrm{z}$ nich nie ma charakteru prawnie wiążącego. $Z$ tego względu raczej intuicyjnie wskazuje się jedynie podstawowe różnice między korporacją międzynarodową a innymi formami aktywności gospodarczej. Także przypisanie podmiotowości napotyka na trudności — brakuje prawnego jednoznacznego pojęcia i zakresu podmiotowości prawnomiędzynarodowej, co prowadzi do zróżnicowania poglądów doktrynalnych.

Nie da się natomiast zaprzeczyć, że korporacji międzynarodowej przyznaje się pewien poziom ochrony w zakresie międzynarodowego prawa praw człowieka — orzecznictwo Europejskiego Trybunału Praw Człowieka jest tego wystarczającym przykładem. Równie silnie w doktrynie brzmi teza o konieczności przestrzegania praw człowieka przez korporacje międzynarodowe, a w wypadku ich naruszania - odpowiedzialności wobec ofiar tych naruszeń. Brak prawnie wiążących rozwiązań w tym zakresie powoduje, że praktycznych rozwiązań w tej kwestii jest wiele, żadne z nich nie jest jednak wystarczająco efektywne. Prowadzone aktualnie w ramach Organizacji Narodów Zjednoczonych prace nad przyjęciem projektu wiążącego aktu prawa międzynarodowego daje pewną nadzieję na przyszłość. Trudno jednak z całą pewnością stwierdzić, czy i w jakiej ostatecznej formie wejdzie on kiedykolwiek w życie.
\end{abstract}

Słowa kluczowe: prawo międzynarodowe, korporacje międzynarodowe, międzynarodowe prawo praw człowieka, odpowiedzialność międzynarodowa, podmiotowość prawna

Korporacje międzynarodowe we współczesnych, zglobalizowanych, stosunkach międzynarodowych odgrywają niewątpliwie bardzo istotną rolę. Ich począt- 
ków doszukać się można już w XVI czy XVII wieku'1, a przykładem może być Brytyjska Kompania Wschodnioindyjska (British East India Company) lub Holenderska Kompania Wschodnioindyjska (Vereenigde Oostindische Compagnie)2 ${ }^{2}$. Oczywiście nie były to korporacje międzynarodowe w dzisiejszym tego słowa znaczeniu, jednakże sama idea ich funkcjonowania wydaje się zbliżona do aktualnego stanu rzeczy. Prawdziwy rozkwit tej formy ekonomicznej aktywności nastąpił po 1945 roku — sprzyjały temu bowiem zarówno sytuacja na świecie, jak i pojawienie się nowych regulacji prawnych ${ }^{3}$. Liczba korporacji międzynarodowych wciąż rośnie, osiągając obecnie skalę powyżej 100 tysięcy ${ }^{4}$. Sama liczba nie stanowi jednakże o znaczeniu tego rodzaju struktur. Niezwykle istotna jest także ich siła ekonomiczna w porównaniu do możliwości finansowych tradycyjnych podmiotów prawa międzynarodowego - państw. Dostępne dane jednoznacznie wskazują, że największe korporacje międzynarodowe znacząco przewyższają w tym zakresie zdecydowaną większość istniejących krajów. Na przykład zestawienie opierające się na przychodach państw i korporacji międzynarodowych za 2016 rok wskazuje, że w pierwszej setce podmiotów o największych przychodach znajduje się 29 państw i 71 korporacji międzynarodowych, przy czym pierwsze osiem miejsc zajmują państwa, a już na dziewiątym znajduje się Walmart ${ }^{5}$.

Zarówno liczba, jak i siła ekonomiczna korporacji międzynarodowych powodują, że ich udział i znaczenie w obrocie międzynarodowym stale rosną. Efekty tej obecności są bardzo zróżnicowane i niejednoznaczne w ocenie. Skutki działań korporacji międzynarodowych widoczne są w wielu obszarach objętych regulacjami prawa międzynarodowego. Jedną z najbardziej wrażliwych sfer ich oddziaływania są prawa człowieka. $Z$ jednej bowiem strony jednostka w relacjach z korporacją międzynarodową ma znacznie słabszą pozycję. Dostępne są już nawet szczegółowe analizy przypadków naruszeń praw człowieka przez korporacje międzynarodowe ${ }^{6}$. Naruszenia te mogą mieć zarówno charakter bezpośredni, jak

${ }^{1}$ P. Muchlinski, Corporations in international law, „Max Planck Encyclopedia of Public International Law" 2014, pkt 3, https:/opil.ouplaw.com/view/10.1093/law:epil/9780199231690/ law-9780199231690-e1513?rskey=KPrSnY\&result=1\&prd=MPIL (dostęp: 7.10.2019).

2 J. Greer, K. Singh, A Brief History of Transnational Corporations, 2000, https://www.globalpolicy.org/empire/47068-a-brief-history-of-transnational-corporations.html (dostęp: 20.01.2020).

3 Ibidem.

${ }^{4}$ Podawane w literaturze liczby różnią się w zależności od przyjętej metody liczenia; por. J. Wouters, A. Chané, Multinational Corporations in International Law, Updated Version: February 2015, s. 4, https://www.researchgate.net/publication/272241501 (dostęp: 25.11.2019); J. Greer, K. Singh, op. cit.

5 M. Babic, E. Heemskerk, J. Fichtner, Who is more powerful — states or corporations?, 2018, http://theconversation.com/who-is-more-powerful-states-or-corporations-99616 (dostęp: 17.01.2020).

6 Zob. M. Özden, Transnational Corporations and Human Rights, 2005, https://www.cetim.ch/wp-content/uploads/Transnational-corporation-and-human-rights.pdf (dostęp: 23.11.2019). Krytyczne analizy aktywności korporacji międzynarodowych można także znaleźć na corpwatch. org czy globalpolicy.org. 
i pośredni ${ }^{7}$. Z drugiej zaś strony coraz częściej wskazuje się, że korporacje międzynarodowe powinny zyskać także ochronę w sytuacji ewentualnych naruszeń praw człowieka wobec nich.

Przedmiotem poniższej analizy będą zatem cztery zagadnienia związane $\mathrm{z}$ korporacjami międzynarodowymi i ich pozycją $\mathrm{w}$ prawie międzynarodowym, a w szczególności międzynarodowym prawie praw człowieka. W pierwszej części przestawione zostaną problemy związane z samym pojęciem korporacji międzynarodowej i jej ewentualnej podmiotowości w prawie międzynarodowym, w drugiej — pozycja korporacji międzynarodowej jako podmiotu z jednej strony uprawnionego do uzyskania ochrony, z drugiej zaś — zobowiązanego do poniesienia odpowiedzialności za naruszenie praw człowieka.

\section{POJĘCIE KORPORACJI MIĘDZYNARODOWEJ}

Próba zdefiniowania pojęcia korporacji międzynarodowej napotyka na wiele trudności. Ich pierwotną przyczyną jest to, iż — podobnie jak w wielu innych wypadkach - prawo międzynarodowe nie ma prawnie i powszechnie wiążącego określenia korporacji międzynarodowej. Następstwem tego jest wielość prób definicyjnych, podejmowanych zarówno przez doktrynę prawa międzynarodowego, jak i przez organizacje międzynarodowe.

W doktrynie można znaleźć bardzo dużo propozycji wypełnienia treścią terminu „korporacja międzynarodowa”. Nie wydaje się konieczne przywoływanie ich w większym wymiarze. Jako przykład można wskazać ujęcie zaproponowane przez P. Muchlinskiego, który uznaje, że prawne ujęcie korporacji związane jest $\mathrm{z}$ jednostką (entity) mającą odrębną osobowość prawną, która może nabywać prawa i zaciągać zobowiązania we własnym imieniu. W takim ujęciu korporacja jest bytem z punktu widzenia prawnego niezależnym od swoich członków ${ }^{8}$. Należy podkreślić, że taką prawną odrębność potwierdził Międzynarodowy Trybunał Sprawiedliwości w sprawie Barcelona Traction ${ }^{9}$ oraz Diallo $^{10}$. W tej ostatniej, w wyroku z 24 maja 2007 roku, Trybunał stwierdził (przywołując orzeczenie Barcelona Traction), że z punktu widzenia prawa międzynarodowego istotna jest ocena, czy danej spółce przyznana została podmiotowość. Jeżeli tak, to wiążą się

7 M. Weschka, Human rights and multinational enterprises: How can multinational enterprises be held responsible for human rights violations Committed abroad?, „Zeitschrift für ausländisches öffentliches Recht und Völkerrecht” 66, 2006, s. 625-661, tu: s. 626.

${ }^{8}$ P. Muchlinski, op. cit., pkt 1.

9 Barcelona Traction, Light and Power Company, Limited Case (Belgium v. Spain), 1970, https://www.icj-cij.org/files/case-related/50/050-19700205-JUD-01-00-EN.pdf (dostęp: 27.01.2020).

10 Ahmadou Sadio Diallo Case (Republic of Guinea v Democratic Republic of the Congo), 2007, https://www.icj-cij.org/files/case-related/103/103-20070524-JUD-01-00-EN.pdf (dostęp: 28.01.2020). 
z nią pewne prawa, których może ona samodzielnie dochodzić ${ }^{11}$. Tak rozumiana korporacja będzie mogła być uznana za międzynarodową, jeżeli jej istnienie będzie wykraczać ponad i poza państwo (państwa) jej działalności ${ }^{12}$.

Jak już wskazano, pewne próby określenia zakresu pojęcia „korporacja międzynarodowa" były podejmowane w ramach organizacji międzynarodowych. Można w tym zakresie wskazać przede wszystkim Organizację Narodów Zjednoczonych (ONZ), Międzynarodową Organizację Pracy (MOP) czy Organizację Współpracy Gospodarczej i Rozwoju (OECD).

Problematyka korporacji międzynarodowych zajmowała i zajmuje znaczące miejsce w ramach prac organów ONZ, szczególnie w kontekście odpowiedzialności za naruszenia praw człowieka. W związku z tym pojawiła się tu konieczność zdefiniowania korporacji międzynarodowej. Pierwszą próbę podjęto w 1974 roku w raporcie przedstawionym Sekretarzowi Generalnemu ONZ przez powołaną przez niego (na wniosek Rady Gospodarczej i Społecznej ONZ ${ }^{13}$ ) grupę ekspertów. W raporcie tym wskazano, że korporacja międzynarodowa to przedsiębiorstwo, które posiada bądź kontroluje obiekty produkcyjne lub usługowe poza granicami państwa-siedziby. W opinii autorów raportu przedsiębiorstwo takie nie musi być jednak prywatne, jego właścicielem może być na przykład państwo ${ }^{14}$.

Z kolei prawie dwadzieścia lat później, w 2003 roku, w dokumencie określającym zasady obowiązków korporacji międzynarodowych w odniesieniu do praw człowieka ${ }^{15}$ przyjęto, że korporacja międzynarodowa to podmiot gospodarczy działający w więcej niż jednym państwie, niezależnie od jego formy prawnej. W świetle tej definicji nie ma także znaczenia, czy działania takiego podmiotu podejmowane są, indywidualnie lub kolektywnie, w państwie-siedzibie czy w innym kraju.

Pod pojęciem tym rozumie się także klaster podmiotów gospodarczych działający w co najmniej dwóch państwach ${ }^{16}$.

Wreszcie w zrewidowanym projekcie ${ }^{17}$ prawnie wiążącego instrumentu mającego za zadanie uregulowanie w międzynarodowym prawie praw człowieka działań

11 Ibidem, pkt 61.

12 S. Khoury, Transnational corporations and the European Court of Human Rights: Reflections on the indirect and direct approaches to accountability, „Sortuz. Oñati Journal of Emergent Sociolegal Studies" 4, 2010, nr 1, s. 68-110, tu: s. 71.

13 Rezolucja Rady Gospodarczej i Społecznej ONZ 1721 (LIII) z 1972 roku.

14 Report of the Group of Eminent Persons to Study the Impact of Multinational Corporations on Development and on International Relations (1974), UN Doc E/5500/Rev.1, ST/ESA/6, s. 25, https://digitallibrary.un.org/record/819904 (dostęp: 23.01.2020).

15 Norms on the Responsibilities of Transnational Corporations and Other Business Enterprises with Regard to Human Rights, UNCHR, Sub-Commission on the Promotion and Protection of Human Rights (26.08.2003), UN Doc E/CN.4/Sub.2/2003/12/Rev.2, https://digitallibrary.un.org/record/501576 (dostęp: 24.01.2020).

16 Ibidem, pkt 21.

17 Będzie on przedmiotem analizy w dalszej części artykułu. 
korporacji międzynarodowych i innych przedsiębiorstw ${ }^{18}$ przyjęto, że działalność biznesowa ma charakter transnarodowy, jeżeli spełnia jeden z trzech warunków: jest podejmowana w zakresie więcej niż jednej jurysdykcji (lub państwa), jest podejmowana w jednym państwie, ale znacząca jej część jest prowadzona w innym, lub jest podejmowana $\mathrm{w}$ jednym państwie, ale jej znaczący efekt ma miejsce $\mathrm{w}$ innym ${ }^{19}$.

Przyjęte $\mathrm{w}$ dwóch innych wymienionych organizacjach dokumenty nie koncentrują się tak bardzo na próbie podania konkretnej definicji, a zadowalają się bardziej ogólną charakterystyką korporacji międzynarodowych. W dokumencie $\mathrm{MOP}^{20}$ stwierdza się bowiem, że konkretna definicja nie jest niezbędna do prawidłowego stosowania tej deklaracji, a wyjaśnienia zamieszczone w jej par. 6 mają bardzo generalny charakter, pozwalający na objęcie nimi bardzo szerokiej grupy podmiotów gospodarczych.

Podobne podejście przyjęto w OECD. W znowelizowanych w 2011 roku wytycznych ${ }^{21}$ przyjęto, że w pojęciu korporacji międzynarodowych zwykle zawierają się spółki lub inne podmioty ustanowione w więcej niż jednym państwie i pozostające w relacjach pozwalających na różnorodne formy koordynacji ich działań ${ }^{22}$.

Trudności w jednolitym rozumieniu pojęcia „korporacja międzynarodowa” pogłębia dodatkowo zróżnicowanie terminologiczne. Zarówno w doktrynie, jak i w dokumentach międzynarodowych w zasadzie równorzędnie występują co najmniej trzy terminy: multinational corporation, transnational corporation i multinational enterprise. Ich stosowanie jest bardzo często zamienne, bez próby wyznaczenia zakresów znaczeniowych, które odróżniałyby je od siebie.

Wydaje się, że można zgodzić się z tezą, że wskazane zróżnicowania pojęciowe $\mathrm{i}$ terminologiczne są $\mathrm{w}$ dużej mierze wypadkową różnorodności form, instrumentów i poziomu integracji podmiotów gospodarczych o międzynarodowym wymiarze. Istotne wydaje się zatem wskazanie elementów, które odróżniają korporacje międzynarodowe od krajowych podmiotów gospodarczych, takich jak: zdolność elastycznego przenoszenia produkcji i majątku między państwami oraz w zasadzie jedynie formalny związek z państwem rejestracji ${ }^{23}$.

18 Revised draft legally binding instrument to regulate, in international human rights law, the activities of transnational corporations and other business enterprises, https://www.ohchr. org/Documents/HRBodies/HRCouncil/WGTransCorp/OEIGWG_RevisedDraft_LBI.pdf (dostęp: 22.11.2019).

19 Ibidem, art. 3 par. 2.

${ }^{20}$ Tripartite Declaration of Principles concerning Multinational Enterprises and Social Policy. Adopted by the Governing Body of the International Labour Office at its 204th Session (Geneva, November 1977) and amended at its 279th (November 2000), 295th (March 2006) and 329th (March 2017) Sessions, https://www.ilo.org/wcmsp5/groups/public/---ed_emp/---emp_ent/--multi/documents/publication/wcms_094386.pdf (dostęp: 22.11.2019).

${ }^{21}$ OECD Guidelines for Multinational Enterprises, 2011, http://www.oecd.org/daf/inv/ mne/48004323.pdf (dostęp: 23.11.2019).

22 Ibidem, pkt 4 cz. 1.

23 J. Wouters, A. Chané, op. cit., s. 6. 


\section{PODMIOTOWOŚĆ PRAWNOMIĘDZYNARODOWA KORPORACJI MIĘDZYNARODOWEJ}

Problematyka podmiotowości międzynarodowej jest jedną z ciągle dyskutowanych kwestii $\mathrm{w}$ doktrynie prawa międzynarodowego. Wynika to głównie $\mathrm{z}$ tego, że w przeciwieństwie do prawa krajowego w prawie międzynarodowym nie ma jednoznacznie sformułowanej normy określającej warunki i sposób nabycia podmiotowości ${ }^{24}$. Poprzez klasyczne ujęcie prawa międzynarodowego jako regulującego stosunki pomiędzy państwami oczywiste było twierdzenie, że tylko państwa są jego podmiotami ${ }^{25}$. Natomiast pojawienie się w obrocie prawnym innych jego uczestników postawiło przed doktryną i sądami międzynarodowymi pytanie, kogo można uznać za podmiot prawa międzynarodowego. Szybko pojawiła się odpowiedź ze strony Międzynarodowego Trybunału Sprawiedliwości. W opinii doradczej z 11 kwietnia 1949 roku w sprawie odszkodowań za szkody poniesione w służbie Narodów Zjednoczonych ${ }^{26}$ Trybunał uznał, że podmiotem prawa międzynarodowego jest ten, kto jest zdolny posiadać międzynarodowe prawa i obowiązki oraz mający zdolność zachowania swoich praw przez wniesienie roszczeń międzynarodowy $\mathrm{ch}^{27}$. Pomimo dość jasnego stanowiska Międzynarodowego Trybunału Sprawiedliwości doktryna prawa międzynarodowego nie wskazuje jednoznacznie, kto jest, a kto nie jest jego podmiotem. Można zatem stwierdzić, że nadal aktualne jest stwierdzenie J. Symonidesa: państwo nie jest jedynym podmiotem prawa międzynarodowego, ale nie wszyscy uczestnicy stosunków międzynarodowych są takimi podmiotami ${ }^{28}$.

W odniesieniu do podmiotowości korporacji międzynarodowej można wyróżnić trzy podejścia:

1. klasyczne - wskazujące, że nie są one podmiotem prawa międzynarodowego $^{29}$;

2. otwarte - pozostawiające sprawę otwartą, nie przesądzając, czy korporacja międzynarodowa jest, czy nie jest, podmiotem prawa międzynarodowego ${ }^{30}$;

3. pozytywne - jasno wskazujące, że korporacja międzynarodowa jest podmiotem prawa międzynarodowego ${ }^{31}$.

Próbą wyjścia z tej — jak się zdaje, niemającej szans na rozstrzygnięcie dyskusji była propozycja spojrzenia na problem z punktu widzenia efektywno-

24 R. Bierzanek, J. Symonides, Prawo międzynarodowe publiczne, Warszawa 1997, s. 121.

25 Ibidem.

${ }^{26}$ Reparation for injuries suffered in the service of the United Nations, Advisory Opinion, https://www.icj-cij.org/files/case-related/4/004-19490411-ADV-01-00-EN.pdf (dostęp: 29.01.2020).

27 Ibidem, s. 9.

28 R. Bierzanek, J. Symonides, op. cit., s. 121.

29 Por. np. I. Brownlie, Principles of Public International Law, Oxford 2008, s. 66; R. Bierzanek, J. Symonides, op. cit., s. 123.

30 Por. np. M. Shaw, International Law, Cambridge 2017, s. 198.

31 J. Wouters, A. Chané, op. cit., s. 7. 
ści. Główną przedstawicielką tego podejścia jest była sędzia i przewodnicząca Międzynarodowego Trybunału Sprawiedliwości R. Higgins. Jej zdaniem bez znaczenia jest formalne przypisywanie komuś podmiotowości międzynarodowej jeżeli działania podejmowane przez korporacje międzynarodowe wywołują rzeczywisty skutek prawny na poziomie międzynarodowym, to jest to wystarczające. Formalny brak podmiotowości nie jest zatem przeszkodą do rozwijania regulacji związanych z prawami i obowiązkami korporacji międzynarodowych $\mathrm{w}$ prawie międzynarodowym ${ }^{32}$.

Można zgodzić się z R. Higgins, że taka formalna dyskusja staje się swego rodzaju „więzieniem intelektualnym”, niemającym żadnych funkcjonalnych następstw $^{33}$. Rację zdaje się też mieć J. Klabbers, pisząc, że:

osobowość nie jest w żadnym wypadku progiem, który należy przekroczyć, aby podmiot mógł uczestniczyć w międzynarodowych stosunkach prawnych; zamiast tego, gdy jednostka uczestniczy, może być użytecznie opisana jako posiadająca międzynarodową osobowość prawną̧34.

Zamiast więc zastanawiać się, czy korporacja międzynarodowa jest, czy nie jest, podmiotem prawa międzynarodowego, lepiej skupić się na zakresie przyznanych jej praw i nałożonych obowiązków. W zakresie międzynarodowego prawa praw człowieka będzie to przedmiotem dalszej analizy.

\section{KORPORACJA MIĘDZYNARODOWA JAKO PODMIOT PRAW WYNIKAJĄCYCH Z MIĘDZYNARODOWEGO PRAWA PRAW CZŁOWIEKA}

Czy korporacja międzynarodowa jest człowiekiem? To nieco absurdalnie brzmiące pytanie nie jest bezzasadne. Prawa człowieka są, jak twierdzi znacząca większość doktryny, przynależne człowiekowi. W jaki zatem sposób uzasadnić objęcie prawami człowieka także korporacji międzynarodowych? Podobnie jak w wypadku podmiotowości doktryna w odniesieniu do objęcia korporacji międzynarodowych jest podzielona. Wskazuje się zarówno argumenty za, jak i przeciw takiemu rozwiązaniu. Do pierwszej grupy można zaliczyć przede wszystkim tezę, iż przyznanie ochrony korporacjom wpływa również na poziom ochrony osób fizycznych, a także wspiera praworządność i demokratyczne społeczeństwo. Część doktryny wskazuje przy tym, że zakres gwarantowanych praw nie może być dokładnie taki sam jak ten oferowany osobom fizycznym ${ }^{35}$. Krytycy zaś takiego podejścia wskazują przede wszystkim na to, że prawami człowieka winny być

32 P. Muchlinski, op. cit., pkt 8.

33 Cyt. za: J. Wouters, A. Chané, op. cit., s. 7.

34 Cyt. za: ibidem.

35 Szerzej na temat możliwych uzasadnień objęcia korporacji prawami człowieka zob. np. A. Scolnicov, Lifelike and lifeless in law: Do corporations have human rights?, „University of 
objęte jedynie istoty ludzkie. Dodaje się także problemy praktyczne, związane na przykład ze znacznym potencjalnym zwiększeniem liczby skarg przy objęciu ochroną korporacji międzynarodowych. Wreszcie pojawia się argument mówiący, że skoro korporacje międzynarodowe nie przestrzegają praw człowieka, to nie mogą z ochrony korzystać ${ }^{36}$. Należy jednak podkreślić, że niezależnie od akceptacji tego czy innego poglądu analiza orzecznictwa sądowego, zarówno krajowego, jak i międzynarodowego, wskazuje, że objęcie korporacji (także międzynarodowych) gwarancjami dostępnymi dotychczas jedynie osobom fizycznym stało się faktem.

W zakresie orzecznictwa sądów krajowych należy wskazać przede wszystkim przełomowe rozstrzygnięcie w USA - sprawa Citizens United $v$ Federal Election Commission została rozstrzygnięta przez Sąd Najwyższy Stanów Zjednoczonych. W wyroku przyjętym większością pięć do czterech Sąd Najwyższy orzekł, że akt prawa amerykańskiego (Bipartisan Campaign Reform Act z 2002 roku) zakazujący korporacjom lub związkom zawodowym wykorzystywanie ich środków finansowych do finansowania „komunikatów wyborczych” lub audycji radiowych, telewizyjnych lub satelitarnych, które odnoszą się do kandydata na urząd federalny w ciągu 60 dni przed wyborami powszechnymi i w ciągu 30 dni od wyborów pierwotnych, jest niezgodny z pierwszą poprawką do Konstytucji Stanów Zjednoczonych, gwarantującą wolność wypowiedzi. W tym zakresie zrównał zatem korporacje i związki zawodowe z osobami fizycznymi ${ }^{37}$. Zarówno samo rozstrzygnięcie, jak i większość, jaką zostało przyjęte, dało asumpt do ożywionej dyskusji dotyczącej obejmowania korporacji uprawnieniami dostępnymi dotychczas jedynie osobom fizycznym ${ }^{38}$.

Natomiast w sferze międzynarodowych organów sądowych jedynie Europejski Trybunał Praw Człowieka zapewnia korporacjom międzynarodowym ochronę wynikającą z Konwencji o ochronie praw człowieka i podstawowych wolności ${ }^{39}$ (dalej: konwencja).

Podstawowe pytanie dotyczy jednak podstaw dopuszczalności skargi korporacji międzynarodowej. Artykuł 1 konwencji stanowi, że państwa będące jej stroną zobowiązane są zapewnić każdemu (ang. everyone, fr. toute personne) po-

Cambridge Faculty of Law Research Paper" 13, 2013, s. 7-16, https://ssrn.com/abstract=2268537 (dostęp: 29.01.2020).

${ }^{36}$ A. Višekruna, Protection of rights of companies before the European Court Of Human Rights, „EU and Comparative Law Issues and Challenges Series” 1. Procedural Aspects of EU Law, 2017, s. 112-114.

37 https://www.oyez.org/cases/2008/08-205 (dostęp: 2.02.2020).

38 B. Landers, Corporations are only human - at least in law, 2010, https://www.opendemocracy.net/en/openeconomy/corporations-are-only-human-at-least-in-law/ (dostęp: 12.10.2019).

39 Konwencja o ochronie praw człowieka i podstawowych wolności, sporządzona w Rzymie dnia 4 listopada 1950 roku (Dz.U. z 1993 r. Nr 61, poz. 284), https://www.echr.coe.int/Pages/home. aspx? $\mathrm{p}=$ basictexts \&c= (dostęp: 28.09 .2019$)$. 
zostającemu w zakresie ich jurysdykcji prawa i wolności w niej zawarte ${ }^{40}$. Pozostaje zatem ustalić, co oznacza termin „każdy”. Dość jednoznacznym wydaje się, że autorzy tekstu konwencji nie mieli wątpliwości, że ma on obejmować także korporacje, a nie tylko osoby fizyczne ${ }^{41}$. $Z$ kolei art. 34 tego aktu prawnego wskazuje podmioty uprawnione do złożenia skargi indywidualnej, wymieniając: każdą osobę, organizację pozarządową i grupę osób, która uważa, że stała się ofiarą naruszenia konwencji. W której z tych grup mieszczą się korporacje międzynarodowe? W świetle prac przygotowawczych i ewolucji ostatecznego brzmienia przepisu zawartego w art. 34 należy stwierdzić, że mieszczą się one w pojęciu organizacji pozarządowej ${ }^{42}$.

Europejski Trybunał Praw Człowieka konsekwentnie, począwszy od pierwszej sprawy wniesionej przez korporację $e^{43}$, udziela im ochrony wynikającej z konwencji. Orzecznictwo Trybunału wskazuje, że przyjął on, iż korporacje są objęte prawami i wolnościami wynikającymi z omawianego aktu prawnego ${ }^{44}$. Oczywiste natomiast jest, że nie wszystkie z nich mogą być przypisywane korporacjom międzynarodowym. Jako podmioty chronione osoby prawne wskazane są tylko w jednym wypadku - ochronie własności, ustanowionej w art. 1 protokołu do konwencji ${ }^{45}$, obejmującej swoim zakresem obowiązek zagwarantowania poszanowania mienia każdej osoby fizycznej lub prawnej ${ }^{46}$. W pozostałym zakresie materialnym konwencji sprawa nie jest już tak jednoznaczna. Aby stwierdzić, które prawa i wolności przysługują korporacjom międzynarodowym, konieczna jest analiza orzecznictwa Trybunału. Jego interpretacja konwencji pozwala bowiem na przypisanie pewnych praw i wolności także korporacjom międzynarodowym.

Najbardziej oczywistym przykładem będzie tu prawo do rzetelnego procesu sądowego ${ }^{47}$. Trudno bowiem znaleźć jakiekolwiek argumenty za odmową przyznania ochrony w tym zakresie również korporacjom (w tym międzynaro-

40 „The High Contracting Parties shall secure to everyone within their jurisdiction the rights and freedoms defined in Section I of this Convention". Należy przy tym wskazać, że w polskim thumaczeniu, niebędącym autentycznym tekstem konwencji, używa się sformułowania „każdemu człowiekowi".

41 W.H.A.M. van den Muijsenbergh, S. Rezai, Corporations and the European Convention on Human Rights, „Global Business \& Development Law Journal” 25, 2012, s. 48. Pojawiają się też tezy odmienne, wskazujące, że ewolucja brzmienia tego przepisu prowadzi do wniosku, iż korporacje międzynarodowe nie są nim objęte; por. A. Scolnicov, op. cit., s. 5.

42 W.H.A.M. van den Muijsenbergh, S. Rezai, op. cit., s. 48.

43 Sprawa 6538/74 The Sunday Times v The United Kingdom, http://hudoc.echr.coe.int/ eng? $\mathrm{i}=001-57584$ (dostęp: 3.02.2020).

44 A. Scolnicov, op. cit., s. 4.

45 Protokół dodatkowy do Konwencji o ochronie praw człowieka i podstawowych wolności z dnia 20 marca 1952 roku.

${ }^{46} \mathrm{~W}$ tekście angielskim: „Every natural or legal person is entitled to the peaceful enjoyment of his possessions", w tekście francuskim (który jest drugim autentycznym tekstem konwencji obok angielskiego): „Toute personne physique ou morale a droit au respect de ses biens”.

47 Art. 6 konwencji. 
dowym). Europejski Trybunał Praw Człowieka wielokrotnie przyznawał taką ochronę w wielu aspektach tego prawa. Dotyczyło to prawa do sprawiedliwego i publicznego rozpatrzenia sprawy przez niezawisły i bezstronny sąd ${ }^{48}$, rozpoznania spraw w rozsądnym terminie ${ }^{49}$, dostępu do sądu ${ }^{50}$ czy też gwarancji równości stron w sprawach cywilnych ${ }^{51}$.

W zakresie innych praw i wolności konwencyjnych nie ma już takiej jednoznaczności. Tym niemniej Trybunał przyznał ochronę korporacjom międzynarodowym również $\mathrm{w}$ zakresie praw i wolności kojarzonych raczej z osobami fizycznymi. Po pierwsze, uznał, że prawo do poszanowania życia prywatnego i rodzinnego (prawo do prywatności) ${ }^{52}$ obejmuje także korporacje międzynarodowe. W sprawie Société Colas Est SA and Others v France ${ }^{53}$ Trybunał wskazał bowiem, że w pewnych okolicznościach prawo do poszanowania mieszkania może także odnosić się do pomieszczeń biznesowych ${ }^{54}$. Po drugie, zdaniem Trybunału korporacjom międzynarodowym przysługuje ochrona związana z wolnością wypowiedzi ${ }^{55}$. Wolność ta była już przedmiotem rozważań w sprawie The Sunday Times $v$ The United Kingdom, w której Trybunał wskazał, że prawo do wolności wypowiedzi gwarantuje nie tylko swobodę prasy w zakresie informowania opinii publicznej, lecz także prawo społeczeństwa do należytego informowania. To dziś już klasyczne podejście zostało wzmocnione w związku ze sprawą Autronic AG $v$ Switzerland ${ }^{56}$. W sprawie tej nie chodziło bowiem o wolność wypowiedzi rozumianą jako swoboda przekazywania informacji, gdyż przekaz skarżącej firmy, na który władze szwajcarskie nie zezwoliły, miał czysto komercyjny charakter. Tym niemniej Trybunał wskazał, że przekaz informacji w celu przekonania do zakupu określonego produktu wchodzi w zakres art. 10 konwencji. Zdaniem Trybunału nie jest bowiem konieczne ustalenie przyczyny i celu, dla którego prawo to jest wykonywane. Ograniczenie czysto komercyjnego odbioru programu telewizyjnego przez władze szwajcarskie zostało więc uznane przez Trybunał za niedozwoloną ingerencję w prawo do wolności wypowiedzi ${ }^{57}$.

48 Sprawa 48553/99 Sovtransavto Holding v Ukraine, http://hudoc.echr.coe.int/eng?i=001-60634 (dostęp: 3.02.2020).

49 Sprawa 11681/85 Unión Alimentaria Sanders SA v Spain, http://hudoc.echr.coe.int/eng?i=001-57618 (dostęp: 3.02.2020).

${ }^{50}$ Sprawa 47650/99 Silvester's Horeca Service v Belgium, http://hudoc.echr.coe.int/eng?i=001-66212 (dostęp: 3.02.2020).

${ }^{51}$ Sprawa 14448/88 Dombo Beheer B.V. V The Netherlands, http://hudoc.echr.coe.int/en$\mathrm{g}$ ? $\mathrm{i}=001-57850$ (dostęp: 3.02.2020).

52 Art. 8 konwencji.

53 Sprawa 37971/97 Société Colas Est SA and Others v France, http://hudoc.echr.coe.int/eng?i=001-60431 (dostęp: 3.02.2020).

${ }^{54}$ Szerzej zob. W.H.A.M. van den Muijsenbergh, S. Rezai, op. cit., s. 54-56.

55 Art. 10 konwencji.

56 Sprawa 12726/87 Autronic AG v Switzerland, http://hudoc.echr.coe.int/eng?i=001-57630 (dostęp: 3.02.2020).

57 Szerzej zob. A. Višekruna, op. cit., s. 118-121. 
Przedmiotem zainteresowania Trybunału stał się także zakres zastosowania art. 41 konwencji w odniesieniu do korporacji. Artykuł ten określa przesłanki ewentualnego orzeczenia przez Trybunał słusznego zadośćuczynienia na rzecz ofiary naruszenia tego aktu prawnego. W tym kontekście jedną $\mathrm{z}$ form słusznego zadośćuczynienia może być przyznanie określonej kwoty za doznane szkody. O ile kompensata finansowa za szkodę majątkową nie budzi wątpliwości, o tyle zrekompensowanie pieniężne szkody niemajątkowej nie jest tak oczywiste, nawet jeżeli ofiarą jest osoba fizyczna. Tym bardziej problematyczne jest przyznanie prawa do słusznego zadośćuczynienia w takiej postaci w odniesieniu do korporacji. Europejski Trybunał Praw Człowieka zmierzył się z tym zagadnieniem w związ$\mathrm{ku}$ z rozpoznawaniem sprawy Comingersoll SA v Portugal ${ }^{58}$. Skarżący przede wszystkim zarzucał oskarżonemu naruszenie uprawnienia do rozpoznania sprawy w rozsądnym terminie przez portugalskie sądy. Jednocześnie wnosił jednak o orzeczenie na jego rzecz rekompensaty pieniężnej (jako formy słusznego zadośćuczynienia) za poniesioną szkodę niemajątkową, związaną z przewlekłością postępowania. Skarżący wskazywał, że zróżnicowanie osób fizycznych i prawnych w kontekście kompensacji finansowej szkody niemajątkowej byłoby bezpodstawne. W wyroku Trybunał podzielił ten pogląd, wskazując, że firmy mogą ponieść szkodę niemajątkową w postaci utraty reputacji, niepewności w zakresie planowania decyzji czy zakłóceń w zarządzaniu spółką. W rozpoznawanej sprawie orzekł, że ,przedłużające się postępowanie cywilne spowodowało, że spółka, jej dyrektorzy i akcjonariusze odczuli znaczne niedogodności i przedłużającą się niepewność", co zdaniem Trybunału uzasadniało przyznanie odszkodowania pieniężnego jako formy słusznego zadośćuczynienia ${ }^{59}$.

Jak wcześniej wskazano, europejski system ochrony praw człowieka jest wyjątkowy, jeżeli chodzi o przyznawanie ochrony korporacjom międzynarodowym w kontekście praw człowieka. W systemie interamerykańskim jednoznacznie wskazano, że korporacje nie podlegają ochronie i nie przysługują im prawa wynikające $\mathrm{z}$ aktów stanowiących materialną podstawę tego systemu ${ }^{60}$. Dość podobnie sytuacja wygląda w odniesieniu do praw wynikających z Międzynarodowego paktu praw obywatelskich i politycznych. Komitet Praw Człowieka w sprawie A newspaper publishing company $v$ Trinidad and Tobago uznał bowiem, że prawo do wniesienia zawiadomienia, na podstawie protokołu dodatkowego do paktu, przysługuje jedynie jednostkom, a zatem zawiadomienie złożone przez spółkę nie może być rozpoznane. Komitet w związku z tym nie odniósł się do zarzutów i kwestii tego, czy korporacji przysługuje ochrona wynikająca z paktu ${ }^{61}$.

58 Sprawa 35382/97 Comingersoll SA v Portugal, http://hudoc.echr.coe.int/eng?i=001-58562 (dostęp: 3.02.2020).

59 Pkt 32-35 wyroku.

60 A. Scolnicov, op. cit., s. 5.

61 Communication No. 360/1989: Trinidad and Tobago. 07/08/89. CCPR/C/36/D/360/1989, http://hrlibrary.umn.edu/undocs/session36/360-1989.html (dostęp: 25.02.2020). 
Można zatem stwierdzić, że przyznawanie korporacjom międzynarodowym ochrony w ramach międzynarodowego prawa praw człowieka ma miejsce, jest ona jednak dość ograniczona, zarówno przedmiotowo, jak i terytorialnie.

\section{KORPORACJA MIĘDZYNARODOWA JAKO \\ PODMIOT ODPOWIEDZIALNY ZA NARUSZENIA MIĘDZYNARODOWEGO PRAWA PRAW CZŁOWIEKA}

Problematyka odpowiedzialności korporacji międzynarodowych za naruszenia praw człowieka stanowiła i wciąż stanowi przedmiot szerokiej dyskusji w doktrynie. Jak wcześniej wskazano, nie ma wątpliwości, że korporacje międzynarodowe w ramach swojej aktywności międzynarodowej dopuszczają się działań lub zaniechań naruszających prawa i wolności innych. Są one dobrze udokumentowane i w zasadzie niepodważalne. Największą bolączką, jak się wydaje, jest jednak to, że naruszenia te dotykają osób szczególnie wrażliwych na naruszania. Dotyczą bowiem dzieci, kobiet lub zasadniczo osób, które nie mają (lub mają w niewielkim stopniu) świadomości istnienia międzynarodowego prawa praw człowieka i wynikających z niego uprawnień podmiotowych. Dodatkowo przez wiele lat przyjmowano, że tylko państwa są zobowiązane w zakresie praw człowieka, a zatem to one ponoszą odpowiedzialność za ewentualne naruszenia. Wszystkie prawnie wiążące akty prawa międzynarodowego, zarówno uniwersalne, jak i regionalne, w pełni się w tę tezę wpisują, wskazując państwa-strony tych regulacji jako zobowiązane do przestrzegania praw w nich zawartych. Obecnie jednak w doktrynie prawa międzynarodowego funkcjonuje pogląd, iż korporacje międzynarodowe także (obok państw) powinny przestrzegać podstawowych standardów praw człowieka. Podejście to wydaje się dobrze ugruntowane ${ }^{62}$. Jednakże, pomijając argumenty natury filozoficzno-moralno-etycznej, pewną trudność stanowi wskazanie formalnoprawnego źródła tego obowiązku, a także jego charakteru. Odnośnie do źródła obowiązku przestrzegania praw człowieka, jak wcześniej wskazano, wiążące regulacje prawne wprowadzają zobowiązania jedynie dla państw. Natomiast w kontekście korporacji międzynarodowych przywołuje się przede wszystkim Powszechną deklarację praw człowieka z 1948 roku (dalej: deklaracja) ${ }^{63}$. Przytacza się wówczas przede wszystkim jej fragment stanowiący, że Zgromadzenie Ogólne ONZ ogłasza deklarację

62 P. Muchlinski, op. cit., pkt 31.

63 Powszechna deklaracja praw człowieka, uchwalona przez Zgromadzenie Ogólne ONZ rezolucją 217/III A w dniu 10 grudnia 1948 roku w Paryżu; tekst polski: http://libr.sejm.gov.pl/tek01/ txt/onz/1948.html (dostęp: 28.09.2019); tekst angielski: https:/www.un.org/en/universal-declaration-human-rights/index.html (dostęp: 28.09.2019). 
jako wspólny standard do osiągnięcia przez wszystkie ludy i wszystkie narody, tak aby każda jednostka i każdy organ społeczny, mając stale na względzie niniejszą Deklarację, dążyły [...] do zapewnienia poszanowania tych praw i wolności, jak również do zabezpieczenia [...] ich powszechnego i skutecznego uznania i przestrzegania $[\ldots]^{64}$.

Przyjmuje się, że użyty tu termin „organ społeczny” (organ of society) obejmuje swoim zakresem między innymi korporacje międzynarodowe. Jednakże ze względu na wątpliwy charakter prawny całej deklaracji (i jej mocy wiążącej) trudno uznać ten zapis (będący częścią preambuły tego aktu prawnego) za wywołujący jednoznaczne następstwa prawne o charakterze więżącym wobec korporacji międzynarodowych ${ }^{65}$. Tym niemniej, jeżeli nawet zaakceptujemy pogląd, że korporacja międzynarodowa powinna przestrzegać standardów ustanowionych w międzynarodowym prawie praw człowieka, wątpliwość wzbudza charakter tego obowiązku. Niewątpliwie nie jest on w swoim charakterze taki sam jak obowiązek państw ${ }^{66}$. Powołany w ramach Organizacji Narodów Zjednoczonych Specjalny Przedstawiciel Sekretarza Generalnego ds. Praw Człowieka i Korporacji Transnarodowych oraz Innych Przedsiębiorstw ${ }^{67}$ w szeregu swoich raportów wskazywał na odrębność obowiązków państw i korporacji międzynarodowych ${ }^{68}$. Jego zdaniem państwa mają obowiązek chronić (protect) prawa człowieka, natomiast korporacje międzynarodowe - szanować (respect) je. W jego optyce ich wspólnym obowiązkiem zaś jest zapewnienie środków zaradczych (joint duty to remedy) ${ }^{69}$.

Wskazane problemy z określeniem podstaw i zakresu obowiązku przestrzegania praw człowieka (przy założeniu, że obowiązek ten jednak istnieje) powodują także trudności w określeniu zasad ich odpowiedzialności oraz mechanizmów jej wyegzekwowania. Brak jednoznacznych prawnie wiążących podstaw sprawia dodatkowo, że w przestrzeni prawnomiędzynarodowej pojawiają się bardzo zróżnicowane próby doprowadzenia do poniesienia odpowiedzialności przez korporacje międzynarodowe.

Pierwszą możliwością jest wyegzekwowanie odpowiedzialności państw przed sądami krajowymi. Potencjalnie są tu dwa dostępne fora: sąd państwa, gdzie miało miejsce naruszenie praw człowieka (o ile nie jest to państwo siedziby), lub sąd państwa-siedziby danej korporacji międzynarodowej. Pierwszy wypadek, teoretycznie

64 „Proclaims this Universal Declaration of Human Rights as a common standard of achievement for all peoples and all nations, to the end that every individual and every organ of society, keeping this Declaration constantly in mind, shall strive [...] to promote respect for these rights and freedoms and by progressive measures, national and international, to secure their universal and effective recognition and observance [...]".

65 P. Muchlinski, op. cit., pkt 34-35.

66 Ibidem, pkt 31.

67 UN Special Representative of the Secretary-General on the issue of human rights and transnational corporations and other business enterprises, https://www.ohchr.org/EN/Issues/Business/ Pages/SRSGTransCorpIndex.aspx (dostęp: 27.01.2020).

68 P. Muchlinski, op. cit., pkt 36.

69 Ibidem, pkt 33. 
dostępny, rzeczywiście jest nierealizowalny. Najczęściej miejscem naruszeń są bowiem państwa rozwijające się, wobec których korporacja międzynarodowa jawi się jako gigant ekonomiczny. Państwa te obawiają się zatem, że próby pociągnięcia korporacji międzynarodowej do odpowiedzialności pociągną za sobą niekorzystne dla niego skutki ekonomiczne ${ }^{70}$. Nadto często korporacje w takich państwa zakładają lokalne spółki-córki, których odpowiedzialność jest dość wątpliwa, a odpowiedzialność spółki-matki trudna bądź wręcz niemożliwa do przeprowadzenia ${ }^{71}$.

Brak praktycznej dostępności postępowań przed wskazanymi sądami powoduje, że ofiary naruszeń podejmują próby wyegzekwowania odpowiedzialności przed sądami państwa-siedziby danej korporacji międzynarodowej, a czasem (jak w wypadku Stanów Zjednoczonych) także przed sądami państwa bardzo słabo związanego z danym naruszeniem (zarówno podmiotowo, jak i przedmiotowo). Praktyka ta jest bardzo zróżnicowana. Najczęściej przywołuje się przykłady postępowań w Wielkiej Brytanii ${ }^{72}$, Stanach Zjednoczonych ${ }^{73}$, Królestwie Niderlandów ${ }^{74}$ czy Francji ${ }^{75}$. Postępowania te wskazują, że forum państwa-siedziby (a nawet państw, gdzie korporacja nie ma siedziby ani naruszenie nie miało miejsca — Stany Zjednoczone) jest pewną możliwością wyegzekwowania odpowiedzialności korporacji międzynarodowej. Problem polega natomiast na zróżnicowaniu zasad, form i mechanizmów w zależności od systemu krajowego. Ponadto przykład orzecznictwa sądów amerykańskich, gdzie początkowo pojawiła się duża szansa na skuteczne przeprowadzanie postępowań wobec korporacji międzynarodowych, a następnie w świetle ostatnich wyroków możliwość tę znacznie ograniczono (a wręcz faktycznie wyłączono), wskazuje, jak niestabilna jest droga dochodzenia odpowiedzialności przed sądami krajowymi.

Świadomość tego, iż korporacje powinny ponosić odpowiedzialność za naruszenia praw człowieka, jest jednak na tyle duża, że w ramach społeczności międzynarodowej próbuje się zapewnić wyższy poziom co najmniej poszanowania praw człowieka przez takie struktury. Przejawia się to w podejmowaniu działań pozasądowych, opartych bądź to na „samoświadomości” korporacji międzynaro-

70 M. Weschka, op. cit., s. 628-629.

71 Zob. np. analizę sytuacji w Nigerii - O.B. Igbayiloye, H.B. Ojibara, A.O. Ugowe, Legal response to human rights challenges of multinational corporations in Nigeria, „Nnamdi Azikiwe University Journal of International Law and Jurisprudence” 6, 2015, s. 106-119, https://www.ajol. info/index.php/naujilj/article/view/136270 (dostęp: 25.02.2020).

72 M. Weschka, op. cit., s. 631-634.

73 Ibidem, s. 634-643; A. Triponel, Business \& human rights law: Diverging rrends in the United States and France, „American University International Law Review” 23, 2007, nr 5, s. 855913, https://digitalcommons.wcl.american.edu/auilr/vol23/iss5/ (dostęp: 4.10.2019).

74 C. Ryngaert, Accountability for corporate human rights abuses: Lessons from the possible exercise of Dutch national criminal jurisdiction over multinational corporations, „Criminal Law Forum" 29, 2018, s. 1-24, https://doi.org/10.1007/s10609-017-9330-y (dostęp: 23.11.2019).

75 A. Triponel, op. cit. 
dowych, bądź to wykorzystujących instrumenty o charakterze soft law, dostępne organizacjom międzynarodowym.

W pierwszym wypadku są to różnego rodzaju wewnętrzne kodeksy postępowania (codes of conduct) przyjmowane samodzielnie przez korporacje międzynarodowe. Jest to niewątpliwie metoda postępowania dość popularna. $Z$ jednej strony bowiem pozwala na szybsze przyjmowanie rozwiązań nienarzucanych, lecz wypracowywanych w ramach korporacji; $\mathrm{z}$ drugiej jednak pojawia się pytanie, czy ich zakres jest wystarczający i na ile korporacja międzynarodowa będzie takich kodeksów wewnętrznych efektywnie przestrzegać ${ }^{76}$.

Ciekawą inicjatywą, także opartą na „samoświadomości”, jest Global Compact $^{77}$. Są to działania organizowane pod egidą Organizacji Narodów Zjednoczonych, których celem jest dobrowolne kształtowanie zasad, strategii i działań przez korporacje międzynarodowe. Ich celem ma być zapewnienie przestrzegania przyjętych standardów w zakresie praw człowieka, ochrony środowiska, prawa pracy, walki z korupcją, a także realizacja innych celów społecznych. Inicjatywa ta staje się coraz bardziej popularna - według stanu na 3 marca 2020 roku jej uczestnikami jest 13987 różnego typu podmiotów ${ }^{78}$. Działanie to niewątpliwie wpisuje się w ideę zrównoważonego rozwoju, która w coraz szerszym zakresie wpływa na działania podejmowane na poziomie relacji międzynarodowych.

Organizacje międzynarodowe, których zakres kompetencyjny w jakimś stopniu dotyczy korporacji międzynarodowych i ich działalności, również starają się wykorzystywać rozmaite dostępne instrumenty o charakterze soft law. Najczęściej są to przyjmowane w organach takich organizacji różnego rodzaju wskazówki (guidelines) czy deklaracje zasad (declaration of principles). Najczęściej przywoływanymi przykładami są wcześniej wskazane OECD Guidelines for Multinational Enterprises ${ }^{79}$, Tripartite Declaration of Principles concerning Multinational Enterprises and Social Policy (przyjęte w ramach MOP) ${ }^{80}$ czy też Guiding Principles on Business and Human Rights (zaakceptowane przez Radę Praw Człowieka ONZ rezolucją 17/4 z dnia 16 czerwca 2011 roku ${ }^{81}$. Wszystkie te dokumenty są do siebie bardzo zbliżone, jeżeli chodzi zarówno o formę, jak i treść. Znajdują się w nich ogólne wskazówki, w jaki sposób powinny zachowywać się zarówno korporacje międzynarodowe, jak i państwa, aby osiągnąć założony cel, to znaczy ograniczenie bądź wyeliminowanie naruszeń praw człowieka. Efekty ich przy-

76 M. Weschka, op. cit., s. 643-645.

77 https://www.unglobalcompact.org (dostęp: 5.10.2019). Szerzej na temat Global Compact zob. M. Weschka, op. cit., s. 650-653.

$78 \mathrm{https}$ //www.unglobalcompact.org/what-is-gc/participants (dostęp: 3.03.2020).

79 Zob. przyp. 21.

80 Zob. przyp. 20.

81 Guiding Principles on Business and Human Rights: Implementing the United Nations 'Protect, Respect and Remedy' Framework, https://www.ohchr.org/Documents/Publications/ GuidingPrinciplesBusinessHR_EN.pdf (dostęp: 22.11.2019). 
jęcia są jednak dość trudne do jednoznacznej oceny. Z jednej strony wyznaczają one pewien oczekiwany przez społeczność międzynarodową standard związany z potrzebą przestrzegania praw człowieka przez organizacje międzynarodowe. $Z$ drugiej - ich charakter prawny i brak formalnej mocy wiążącej pozostawiają dość duży margines swobody dla tych, do których są skierowane.

Wszystkie te słabości już istniejących rozwiązań powodują, że w dyskusji prawnomiędzynarodowej od pewnego czasu pojawia się postulat przyjęcia formalnie wiążących rozwiązań, które pozwalałyby na wyegzekwowanie odpowiedzialności korporacji międzynarodowych za naruszanie praw człowieka ${ }^{82}$. Wydaje się jednak, że propozycje te, nie wchodząc w dyskusję o ich istocie, mają małe szanse realizacji, biorąc pod uwagę dotychczas podejmowane kroki w kierunku przyjęcia $\mathrm{w}$ prawie międzynarodowym rozwiązań prawnie wiążących.

Po raz pierwszy taka próba została podjęta w ramach ONZ w 2003 roku. W sierpniu tego roku Podkomisja ONZ ds. Promocji i Ochrony Praw Człowieka przyjęła projekt instrumentu prawnego pod nazwą Norms on the Responsibilities of Transnational Corporations and other Business Enterprises with regard to Human Rights ${ }^{83}$. W przeciwieństwie do wskazanych wcześniej dokumentów o charakterze soft law projekt ten miał w założeniu stać się wiążącą regulacją prawnomiędzynarodową. Dlatego jego treść jest znacznie bardziej konkretna i jednoznaczna niż wcześniejszych opracowań. Zgodnie z postanowieniami projektu zasady w nim zawarte miały zostać implementowane do wewnętrznych polityk korporacji międzynarodowych oraz umów przez nich zawieranych (miałyby one obowiązek także współpracować jedynie z podmiotami wspierającymi wskazane w projekcie zasady). Z kolei państwa miały być zobowiązane do zapewnienia ram niezbędnych do implementacji tych zasad. Wreszcie przewidziany był okresowy proces monitoringu i weryfikacji implementacji zasad wynikających z Norms on the Responsibilities przez ONZ oraz inne istniejące i projektowane ciała. Niestety Komisja Praw Człowieka ONZ w 2004 roku stwierdziła między innymi, iż pomimo że Norms on the Responsibilities przypominają umowę międzynarodową, to jednak są tylko projektem i jako takie nie mają znaczenia prawnego ${ }^{84}$. Pomimo że nie przekształciły się one w wiążącą umowę międzynarodową, wypada zgodzić

${ }^{82}$ Zob. np. Ch. Zarpaylic, The legal justification for an International Tribunal for Corporate Violations: Lessons from Nuremberg, „Ramapo Journal of Law and Society” 2018, wydanie jesienne, s. 34-57, https://www.ramapo.edu/law-journal/thesis/the-legal-justification-for-an-internatio nal-tribunal-for-corporate-violations-lessons-from-nuremberg/ (dostęp: 20.10.2019); D. Cassell, A. Ramasastry, White paper: Options for a Treaty on Business and Human Rights, „Notre Dame Journal of International \& Comparative Law" 6, 2016, nr 1, s. 1-50, http://scholarship.law.nd.edu/ ndjicl/vol6/iss1/4 (dostęp: 7.10.2019).

83 Norms on the Responsibilities of Transnational Corporations and other Business Enterprises with regard to Human Rights E/CN.4/Sub.2/2003/12/Rev.2, https://digitallibrary.un.org/ record/501576 (dostęp: 22.11.2019).

${ }^{84}$ M. Weschka, op. cit., s. 653-656. 
się, że poprzez swoje skonkretyzowanie mogły stanowić znakomitą podstawę do dalszych prac nad taką umową ${ }^{85}$.

Prace takie rzeczywiście zostały podjęte, ale dopiero dziesięć lat później — 26 czerwca 2014 roku Rada Praw Człowieka ONZ przyjęła rezolucję 26/9 (inicjatywę w tej sprawie zgłosił Ekwador), na mocy której powstała Otwarta Międzyrządowa Grupa Robocza ds. Korporacji Transnarodowych i Innych Przedsiębiorstw Biznesowych w odniesieniu do Praw Człowieka ${ }^{86}$. Celem prac tej grupy miało być przygotowanie projektu prawnie wiążącego instrumentu regulującego w międzynarodowym prawie praw człowieka działalność międzynarodowych korporacji i innych przedsiębiorstw. W trakcie czwartej sesji tej grupy (w dniach 15-19 października 2018 roku) omawiane były dwa dokumenty: Zero draft legally binding instrument to regulate, in international human rights law, the activities of transnational corporations and other business enterprises oraz Zero draft optional protocol. W wyniku dyskusji w trakcie tej sesji, a także po niej, przed kolejną, piątą sesją Ekwador (w imieniu przewodniczącego grupy) przedstawił 16 lipca 2019 roku poprawioną wersję projektu pod nazwą Revised draft legally binding instrument to regulate, in international human rights law, the activities of transnational corporations and other business enterprises. Piąta sesja odbyła się w Genewie w dniach 14-18 października 2019 roku. Do końca lutego 2020 był czas na przedstawianie uwag do dyskutowanego projektu. Zapewne wkrótce zostanie ogłoszony termin kolejnej sesji grupy roboczej ${ }^{87}$.

Trudno jednak jednoznacznie ocenić treść tego projektu, ponieważ jego ostateczna wersja nie jest jeszcze skonkretyzowana. Zastrzeżenia i uwagi można odnaleźć w raportach grupy ${ }^{88}$, a także dostępnych analizach doktrynalnych ${ }^{89}$. Trudno także określić, czy i kiedy projekt ten stanie się wiążącą literą prawa. Biorąc pod uwagę wcześniejsze prace w zakresie uregulowania odpowiedzialności korporacji międzynarodowych oraz innych prac dotyczących na przykład odpowiedzialności państw za naruszenia prawa międzynarodowego, niełatwo tu o specjalny optymizm. Być może jednak istota problemu oraz zmiany w świadomości — zarówno państw,

${ }^{85}$ Ibidem, s. 656.

86 Open-Ended Intergovernmental Working Group on Transnational Corporations and Other Business Enterprises With Respect to Human Rights.

87 Strona internetowa grupy: https:/www.ohchr.org/EN/HRBodies/HRC/WGTransCorp/ Pages/IGWGOnTNC.aspx (dostęp: 1.03.2020). Na stronie można znaleźć informacje na temat jej prac, kalendarz sesji oraz dokumenty związane z pracami grupy roboczej.

88 https://www.ohchr.org/EN/HRBodies/HRC/WGTransCorp/Pages/IGWGOnTNC.aspx (dostęp: 1.03.2020).

89 C. Lopez, Toward an International Convention on Business and Human Rights, 2018, https://www.iisd.org/itn/2018/10/17/toward-an-international-convention-on-business-and-humanrights-carlos-lopez/ (dostęp: 29.02.2020); idem, The revised draft of a Treaty on Business and Human Rights: Ground-breaking improvements and brighter prospects, 2019, https://www.iisd. org/itn/2019/10/02/the-revised-draft-of-a-treaty-on-business-and-human-rights-ground-breakingimprovements-and-brighter-prospects-carlos-lopez/ (dostęp: 29.02.2020). 
jak i korporacji międzynarodowych — spowodują, że wreszcie w przestrzeni prawa międzynarodowego pojawi się prawnie wiążący instrument (umowa) określający nie tylko zasady odpowiedzialności, lecz także procedury jej wyegzekwowania.

\title{
MULTINATIONAL CORPORATIONS AS A SUBJECT (?) OF INTERNATIONAL HUMAN RIGHTS LAW
}

\begin{abstract}
Summary
Multinational corporations participate in international relations, whose origins can be traced back to as early as the 17 th century. Currently, the consequences of their activity can be seen in various areas covered by international law, including in international human rights law. On the one hand, there are numerous, fairly well-documented examples of human rights violations. On the other, the view is being expressed increasingly more often regarding the need to extend protection previously available to human beings also to multinational corporations. Therefore, it seems important to determine their position in international human rights law. The doctrine of international law has a number of definitional attempts, but none of them is legally binding. Therefore, only basic differences between a multinational corporation and other forms of economic activity are indicated rather intuitively. Attribution of subjectivity also faces difficulties — the lack of a legal unambiguous concept and scope of legal-international subjectivity leads to a diversity of doctrinal views. But it cannot be denied that a multinational corporation is granted a certain level of protection in the field of international human rights law - the case law of the European Court of Human Rights is a sufficient example. Equally strong in the doctrine is the thesis that multinational corporations must respect human rights, and in the event of their violation - responsibility towards the victims of these violations. The lack of legally binding solutions in this area means that there are many practical solutions in this area, but none of them are effective enough. The ongoing work under the United Nations to adopt a draft binding act of international law gives some hope for the future. However, it is difficult to say with certainty whether and in what final form it will ever enter into force.
\end{abstract}

Keywords: international law, multinational corporation, international human rights law, international responsibility, legal personality

\section{BIBLIOGRAFIA}

Babic M., Heemskerk E., Fichtner J., Who is more powerful — states or corporations?, 2018, http:// theconversation.com/who-is-more-powerful-states-or-corporations-99616.

Bierzanek R., Symonides J., Prawo międzynarodowe publiczne, Warszawa 1997.

Brownlie I., Principles of Public International Law, Oxford 2008.

Cassell D., Ramasastry A., White paper: Options for a treaty on business and human rights, „Notre Dame Journal of International \& Comparative Law" 6, 2016, nr 1.

Greer J., Singh K., A Brief History of Transnational Corporations, 2000, https://www.globalpolicy. org/empire/47068-a-brief-history-of-transnational-corporations.html.

Igbayiloye O.B., Ojibara H.B., Ugowe A.O., Legal response to human rights challenges of multinational corporations in Nigeria, „Nnamdi Azikiwe University Journal of International Law and Jurisprudence" 6, 2015. 
Khoury S., Transnational corporations and the European Court of Human Rights: Reflections on the indirect and direct approaches to accountability, „Sortuz. Oñati Journal of Emergent SocioLegal Studies" 4, 2010, nr 1.

Landers B., Corporations are only human - at least in law, 2010, https://www.opendemocracy.net/en/ openeconomy/corporations-are-only-human-at-least-in-law/.

Lopez C., The revised draft of a Treaty on Business and Human Rights: Ground-breaking improvements and brighter prospects, 2019, https:/www.iisd.org/itn/2019/10/02/the-revised-draft-of-atreaty-on-business-and-human-rights-ground-breaking-improvements-and-brighter-prospectscarlos-lopez/.

Lopez C., Toward an nternational Convention on Business and Human Rights, 2018, https://www. iisd.org/itn/2018/10/17/toward-an-international-convention-on-business-and-human-rights-carlos-lopez/.

MuchlinskiP., Corporations in international law, „Max Planck Encyclopedia of Public International Law” 2014, https://opil.ouplaw.com/view/10.1093/law:epil/9780199231690/law-9780199231690-e 1513?rskey=KPrSnY\&result=1\&prd=MPIL.

Muijsenbergh W.H.A.M. van den, Rezai S., Corporations and the European Convention on Human Rights, „Global Business \& Development Law Journal” 25, 2012.

Özden M., Transnational Corporations and Human Rights, 2005, https://www.cetim.ch/wp-content/ uploads/Transnational-corporation-and-human-rights.pdf.

Ryngaert C., Accountability for corporate human rights abuses: Lessons from the possible exercise of Dutch national criminal jurisdiction over multinational corporations, „Criminal Law Forum” 29, 2018.

Scolnicov A., Lifelike and lifeless in law: Do corporations have human rights?, „University of Cambridge Faculty of Law Research Paper" 13, 2013.

Shaw M., International Law, Cambridge 2017.

Triponel A., Business \& human rights law: Diverging trends in the United States and France, „American University International Law Review" 23, 2007, nr 5.

Višekruna A., Protection of rights of companies before the European Court of Human Rights, „EU and Comparative Law Issues and Challenges Series" 1. Procedural Aspects of EU Law, 2017.

Weschka M., Human rights and multinational enterprises: How can multinational enterprises be held responsible for human rights violations committed abroad?, „Zeitschrift für ausländisches öffentliches Recht und Völkerrecht” 66, 2006.

Wouters J., Chané A., Multinational Corporations in International Law, Updated Version: February 2015, https://www.researchgate.net/publication/272241501.

Zarpaylic Ch., The legal justification for an International Tribunal for Corporate Violations: Lessons from Nuremberg, ,Ramapo Journal of Law and Society” 2018, wyd. jesienne. 